\title{
Exploration of sterilization method and type of media for in vitro propagation of bauhinia scandens
}

\begin{abstract}
This study aims to obtain an appropriate sterilization method and media for propagation of Bauhinia scandens in vitro. The study was conducted at the Tissue Culture Laboratory and Biology Greenhouse. The method used in this study was induction using cytokinin BAP (benzyl amino purine) in MS media. Explain obtained from seed seeds that have been germinated in polybags with soil media and compost. Sterilization for planting with tissue culture techniques using detergents, $70 \%$ alcohol, $20 \%$ and $10 \%$ Clorox, and sterile aqua dest. The media used were MS (Murashige and Skoog) media plus BAP (concentrations of 2 and $4 \mathrm{ppm})$, as well as 2,4-D (0.4, 1.0, and $1.5 \mathrm{ppm})$ and the tones, were added with activated charcoal. The results showed that the addition of BAP in MS media was able to trigger the growth of shoots in explorer node bauhinia at concentrations of 2 and $4 \mathrm{ppm}$. The addition of 2,4-D was able to induce callus in Bauhinia scandens leaves. At a concentration of $1 \mathrm{ppm}$ the callus produced was white, runny with leaves that were not too curled while concentrations of 0.4 and $1.5 \mathrm{ppm}$ produced green callus with curled leaves. More varied media treatments need to be performed on both nodes and leaf explants to produce plantlets through callus or shoot formation directly.
\end{abstract}

Keywords: exploration, sterilization, media, in vitro, propagation
Volume 3 Issue 5 - 2019

\author{
Lianah Kuswanto \\ Department of Biology, Faculty of Science and Technology, \\ Prof. Hamka (Kampus II), Universitas Islam Negeri Walisongo, \\ Indonesia \\ Correspondence: Lianah Kuswanto, Department of Biology, \\ Faculty of Science and Technology, Prof. Hamka (Kampus II), \\ Universitas Islam Negeri Walisongo, Ngaliyan, Semarang City \\ 50185, Central Java, Indonesia, \\ Email lianahkuswanto@yahoo.co.id
}

Received: October 21, 2019 | Published: October 29, 2019

\section{Background}

Bauhinia scandens is a unique plant that is already rare, especially in Semarang, Central Java. It is found to be the largest in Sam Poo Kong, around 600 years old with a diameter of $65 \mathrm{~cm}$. As for the others found in the Pagerwunung Darupono Kaliwungu Kendal Nature Reserve. ${ }^{1}$ However, with the widespread observation or exploration that chain trees were found to be in the public cemetery/grave of Tugurejo Semarang with a diameter of 20-35 cm and in Silayur Mijen Diameter 4-10 cm. Also in the village of Pidi Kec Pengonon 5-10 cm also in Goa Kreo diameter 20-25 cm, near the Sewu Sukorjo waterfall and in the Sukorjo Protection Forest, there are also, but all are still small. The uniqueness of this liana plant is always clustering suspected of breeding in addition to the seeds as well as their root buds so that clustered between 1-17 trees in CA Pagerwunung Darupono, 1-10 trees in Silayur Ngaliyan Semarang that can be counted significantly.

Breeding through seeds is quite difficult. It has been proven that several seeding from 100 seeds in experiment I and 68 seeds in experiment II the only one can grow into a complete plant to a height of $10 \mathrm{~cm}$ on day 6 . But not for a long time the brown roots die. Therefore it is necessary to do the propagation method using tissue culture biotechnology which is one of the efforts to multiply in large quantities and quickly. In addition to these rare plants are thought to have medicinal properties. And one of the obstacles in the cultivation of chain tree plants is the difficulty in getting seedy seeds. Currently, conventional seeds are still being procured from the parent tree.

Tissue culture technique is one technique that can be used in the multiplication of Bauhinia scanden plants (tree chains). The advantages of tissue culture include a faster propagation cycle for plants, enabling vegetative propagation for plants that are difficult or impossible to propagate vegetatively, and the resulting seedlings are healthy seeds. ${ }^{2}$ This study aims to produce appropriate sterilization methods and media for propagation of chain tree plants with tissue culture so that they can be used to obtain uniform seeds in large quantities.

\section{Literature review}

As part of the Indo-Malayan region, Indonesia is one of the eight centers of plant genetic diversity in the world, especially for tropical medicines including Bauhinia sp, as well as Zingiberaceae and spices. In Indonesia, there are various types of plants of the genus Bauhinia upright trees and Bauhinia liana (vines).

Micropropagation or in vitro techniques are often used to produce plants that are true-to-type or called clones or the same as the original plants. ${ }^{1}$ Bauhinia scandens tissue culture is still rarely performed. From several publications, only a few do micropropagation using vegetative parts such as shoots for propagation by tissue culture. This is caused by the difficulty of doing micropropagation of woody plants. ${ }^{3}$ In a study conducted by Karsinah, ${ }^{4}$ explants of B. scandens cotyledons grown on media with 0.1-0.5 ppm 2,4-D and 0.5-2.0 ppm BAP produced callus growth, whereas. ${ }^{5}$ used $1 \mathrm{mg} /$ liter BAP to induce lateral durian buds in vitro.

\section{Research methods}

Research has been conducted in the experimental garden and tissue culture laboratory, Faculty of Mathematics and Natural Sciences, Semarang State University. The material used is chain tree seeds from Sam Poo Kong Semarang. Seed germination is carried out in the experimental garden by planting seeds in polybags containing soil and compost media. For seed germination, medium size polybags are needed, planting media (compost and soil) and farming equipment. 
After the buds begin to appear, nodes and leaves are transferred to MS media containing BAP cytokinins. For sterilization, ingredients such as detergents, bactericides, fungicides, distilled water, 70\% alcohol, $10 \%$ Clorox (bayclin) solution, and tissue are used. Aluminum foil and paper umbrella are also used in the sterilization of tools. The media used were $\mathrm{MS}+2 \mathrm{ppm} \mathrm{BAP}$ and $\mathrm{MS}+4 \mathrm{ppm}$ BAP for shoot induction from nodia, while for callus induction in leaves the MS media was used with an additional 2.4-D (0.4 ppm, $1 \mathrm{ppm}$, and $1.5 \mathrm{ppm})$ In vitro treatment, tools such as media bottles and heat-resistant caps or aluminum foil are needed. Tweezers, Bunsen lamps, scalpels, Petri dish, beakers, magnetic stirrers, autoclaves, digital scales, labels, and Laminar airflow (LAF) cabinets will also be used. ${ }^{6,7}$

\section{Results and discussion}

Chain tree germination is carried out in soil media because in vitro germination is difficult. ${ }^{1}$ With several methods of seed sterilization, contamination still occurs when planted in vitro media. Therefore, attempts to obtain a sterile explant source cannot be done. Of the several sterilization methods 3 tried, the best results were obtained with $20 \%$ and $10 \%$ Clorox sterilization methods and $70 \%$ alcohol for explant nodia, with a soaking time of 5 minutes. For leaves, sterilize with Clorox $10 \%$ and $5 \%$ and $70 \%$ alcohol with soaking time in each solution for 3 minutes. The addition of BAP in MS media was able to induce shoots in nodia

Bauhinia scandens with BAP concentrations of 2 and $4 \mathrm{ppm}$. At a concentration of $2 \mathrm{ppm}$, BAP induces the formation of shoots only on nodes while a concentration of $4 \mathrm{ppm}$ induces the formation of nodes and callus. This can be caused by cytokines that have been in explants since they have been taken from germination seeds. The origin of the explant, specifically the genotype and position of the explant in the parent plant will determine the level of endogenous hormones in the explant. ${ }^{8}$ Shoots that form on media with 2 ppm BAP require a longer time to grow, whereas with $4 \mathrm{ppm}$ BAP shoots appear faster but with callus growth on the node part. The callus that grows is a dense callus with a smooth yellow outer surface (Figure 1).

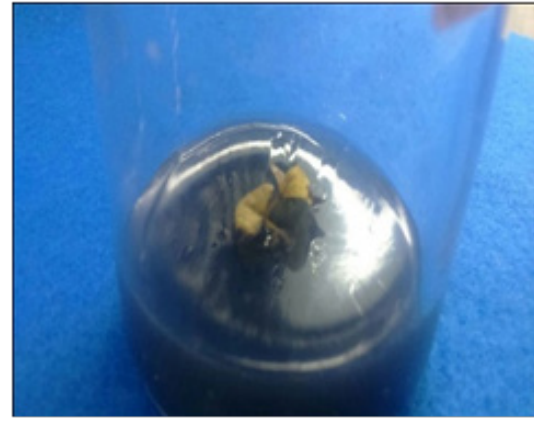

1. Media b511k2

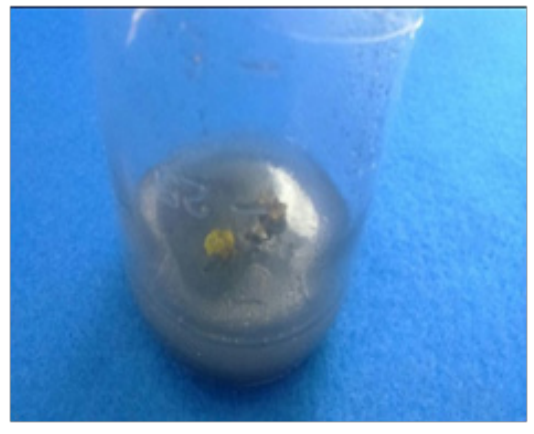

2. Media b5 bap dan tdz

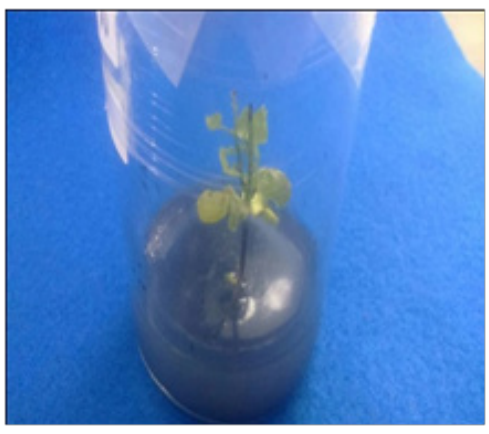

3. Media b5 bap dan tdz

Figure I Growth of Bauhinia scandens nodia explants in vitro with the use of MS+2 ppm BAP media at 8 weeks after planting.

MS media containing 2,4-D auxin were able to induce callus growth in bauhinia leaf explants. A concentration of $0.4 \mathrm{ppm} 2,4-\mathrm{D}$ is only able to make the leaves curl up and look like indentations like a large callus. Auxin 2,4-D with a concentration of $1 \mathrm{ppm}$ produces a white, dense and aqueous callus, while a concentration of $1.5 \mathrm{ppm}$ produces a larger, faster but green callus (Figure 2). Treatments 1 and 1.5 ppm 2,4-D did not cause the leaves to curl as in the 0.4 ppm treatment so that absorption of nutrients by the leaf surface still attached to the media was more effective. The results obtained show the influence of 2,4-D as auxin which causes cell elongation, tissue swelling, and callus formation. ${ }^{5}$ Adventitious root formation was not seen in this study although auxin was able to trigger the growth of adventitious roots. The potential for embryogenesis is seen in treatments with a concentration of $1 \mathrm{ppm} 2,4-\mathrm{D}$. The type of callus that is formed resembles the callus induced by auxin in explants internode tree plants in the family Caesalpinioideae, Leguminosae. ${ }^{9}$ Callus formed globular and solid / not a crumb. This type of callus has the potential to be induced to form buds.

In Figure 2. Development of bauhinia leaf explants 4 weeks after planting. Treatments on MS media with (a) $0.4 \mathrm{ppm} 2,4-\mathrm{D}$, (b) $1.0 \mathrm{ppm}$ 2,4-D, and (c) 1.5 ppm 2,4-D.

A callus is a collection of amorphous cells that occur from tissue cells. Callus formation in wound tissue is stimulated by endogenous auxin growth regulators and cytokinins ${ }^{10}$ In vivo, callus generally forms on scars due to infectious microorganisms such as Agrobacterium tumefaciens, nematodes, insect bites or punctures. Callus can also be formed as a result of stress ${ }^{11}$ there are several problems in tissue culture, which must be considered in the implementation of tissue culture, namely tissue culture media which plays an important role in supporting tissue growth consisting of macro and microelements. Amino acids, body-regulating substances, sugar instead of carbon, are also composed of vitamins, compacting agents in the form of agar and natural complex compounds. ${ }^{4}$ Nutrients are macroelements and microelements such as $\mathrm{N}, \mathrm{P}, \mathrm{K}, \mathrm{Ca}, \mathrm{Mg}, \mathrm{S}, \mathrm{Fe}, \mathrm{Cu}, \mathrm{Mn}, \mathrm{Zn}, \mathrm{Mo}$, and Co. Each of these elements has an important role in the formation of chlorophyll, proteins, enhances the activity of enzymes and activates the formation of meristematic tissue, translocation of carbohydrates and others. Furthermore, it is said that carbohydrates in addition to energy sources for plants are also a source of nutrients that contribute to the growth of plant cell culture and are also a source of nutrition that plays a role in the growth of plant cell culture. This carbon source is used as an energy producer in the process of respiration, new cell growth and in high concentrations can stimulate root growth. The condition of the tissue culture environment is another factor that largely determines success in tissue culture. ${ }^{12}$

These environmental factors include light, temperature, and $\mathrm{pH}$ of the media. The role of light on growth is determined by the length of exposure. Good light intensity of lamps between $100-400 \mathrm{Ft}-0 .{ }^{13}$ The growth of tissue culture requires a certain temperature. In general, tissue culture grows well at a temperature of $20 \mathrm{C}$ to $28 \mathrm{C} .{ }^{12}$ To control the room temperature, tissue culture is assisted with AC. ${ }^{14,15}$ 


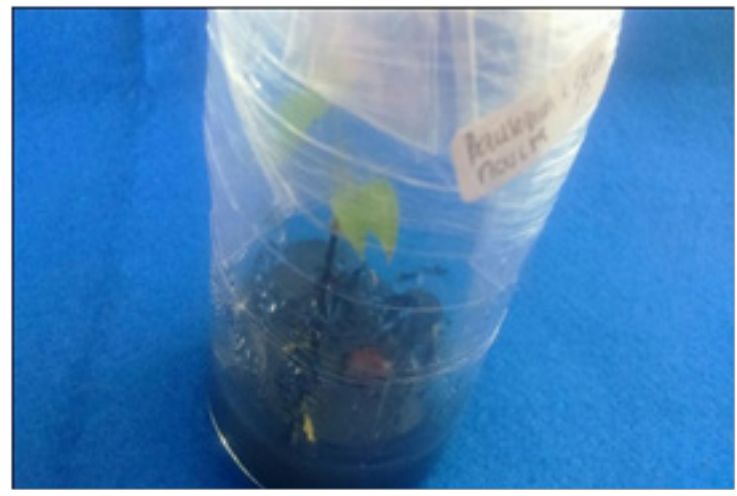

Gamb: 4 Media b5 bap dan tdz

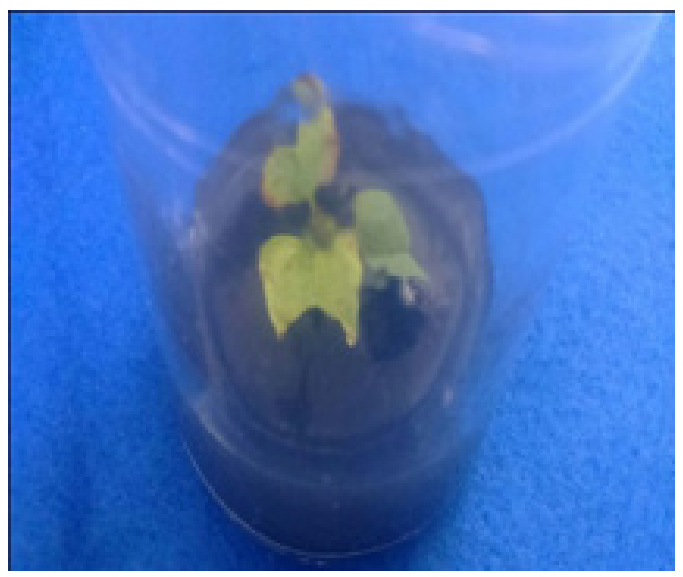

Gb.6 Media wpm kinetin tdz

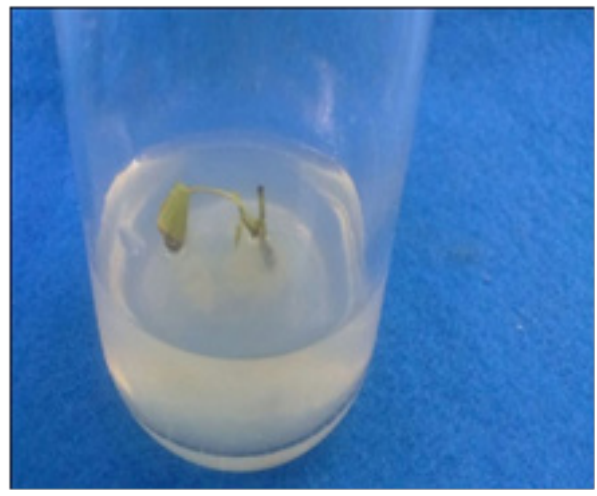

Gb 5 Media w2ip

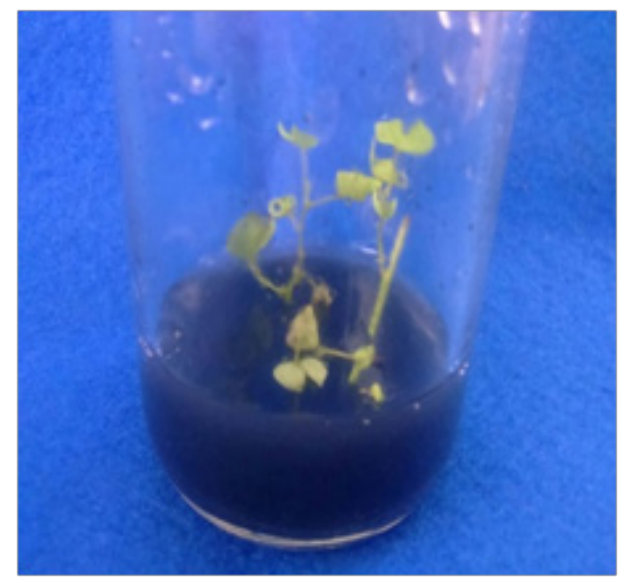

7 Media wki (wpm kinetin dan iaa

Figure 2 Growth of Bauhinia Scandens nodia explants in vitro with use of MS +4 ppm BAP at 4 weeks after planting.after planting.

\section{Conclusion}

Research shows that BAP with concentrations of 2 and $4 \mathrm{ppm}$ on MS media is able to induce shoots of Bauhinia scandens nodia in vitro. A concentration of $4 \mathrm{ppm}$ also induces callus in addition to shoots. The addition of 2,4-D auxin was able to induce callus in explants of Bauhinia scandens leaves originating from seedlings aged 1 month, at concentrations of 1 and $1.5 \mathrm{ppm}$. A concentration of $0.4 \mathrm{ppm} \mathrm{2,4-}$ D causes leaf explants to curl but no callus is formed. Exploration needs to be done with concentrations of growth regulators that are more varied and with certain combinations (for example auxin and cytokinin in one media).

\section{Acknowledgments}

Thank you to the Ministry of Religion Dictation for providing research funding and Novita UNNES Culture Lab Assistant for technical tissue culture.

\section{Conflicts of interests}

Authors declare no conflict of interest exists.

\section{References}

1. Karsinah, R. Triatminingsih, Sunyoto. In vitro hypocotyl, cotyledon, and cotile ring cultures. Penelitian Hortikultura. 1995;7(2):1-10.

2. George EF. Plant propagation by tissue culture: the technology, Part 1. 2nd ed. Exegetics Limited. London.1993:150.

3. Giri CC, B Shyamkumar, C Anjaneyulu. Progressin tissue culture, genetic transformation and applications of biotechnology to trees: an overview. Trees. 2004;18:115-135.

4. Jolanda AJ. Substitusi media MS dengan air kelapa dan gandasil-D pada kultur jaringan krisan. Eugenia. 2003;9(4):203-211.

5. Namhomchan S. In Vitro culture of durian.thesis. Kasetsart University. Bangkok. 1999.

6. Anonim. Durian. Durian research centre. fakultas pertanian. Universitas brawijaya (DRC-FPUB). Diakses tanggal 20 Maret 2012.

7. BPP. Teknologi. Durian (Bombaceae sp.). Menegristek field of science and technology empowerment and correctional. Jakarta. Diakses tanggal 20 Maret. 2012.

8. Pierik RML. In Vitro culture of higher plants. Martinus Nijhoff Publishers. Dordrecht. The Net. 1987. 
9. Lianah L. Idris F, Krisantini K. Short communication: analysis of the chemical constituents and micromorphology of Bauhinia scandens using sem-eds techniques. Biodiversitas. 2019;20:2055-2060.

10. Sandra E. Household-scale orchid tissue culture. Jakarta: Agromedia pustaka. 2006.

11. Siregar LM, Chan Lai Keng, dan Boey Peng Lim. Growth and accumulation of alkaloids in callus and eurycoma longifolia jack cell suspension. Jurnal Ilmiah Pertanian Kultura. 2006;41(1):19-27.

12. Zulkarnain H. Plant tissue culture the multiplication solution of cultivated plants. Jakarta: Bumi Aksara. 2000.
13. Wijayani A. Bioteknologi. Yogyakarta: UGM Press. 1994.

14. Agrawal V, SC Gupta. Rapid micropropagation of populus $\mathrm{x}$ euramericana trees by callus culture. In: LK Pareek, editor. Trends in Plant Tissue Cultureand Biotechnology. Agrobios. Jodphur. 2005:262.

15. Lianah. Morphological characteristic of a unique 'chain tree' Bauhinia scandens willd (Caesalpinioideae, Leguminosae) from pager wunung conservation park, central Java, Indonesia. Journal of Tropical Crop Science. 2016;3:56-60. 